\title{
INVESTIGATING THE NEED TO REINTRODUCE A BALLOT REQUIREMENT FOR A PROTECTED STRIKE IN SOUTH AFRICA
}

\author{
Mlungisi Tenza \\ LLB LLM LLD \\ University of KwaZulu-Natal
}

\begin{abstract}
SUMMARY
The issue of violent and protracted strikes has been a source of debate on many labour platforms in South Africa. Unions believe that if a ballot is introduced as one of the requirements for a protected strike in South Africa, it will be abused by employers and manipulated as was the case under the old Labour Relations Act. A counterargument is that no one can take away a right in the Bill of Rights unless the prescribed procedure in the Constitution is followed. A right in the Bill of Rights can also not be limited unless the limitation is in terms of section 36 of the Constitution. Of particular importance to this issue is not the number of strikes in South Africa but their nature (which has been violent) and their duration (which has been unreasonably long). The violent nature of strikes is a major concern for employers, society and non-striking employees. Violent and lengthy strikes are dangerous to both employers and employees. The employer suffers loss of profit and loss of clients with the possibility of reducing its workforce or closing its business. Employees, on the other hand, face retrenchments if the business is not making a profit. The article argues that the reintroduction of a ballot requirement will play a meaningful role in reducing the number of strikes and their duration. Balloting employees prior and during the course of a strike will help test whether employees have the appetite for the strike. The article further argues that if long strikes can be reduced through ballots, dismissal on the basis of operational requirements could be avoided. In the long run, poverty arising from high levels of unemployment could be avoided.
\end{abstract}

\section{$1 \quad$ INTRODUCTION}

The issue of whether members of a union that intends to convene a strike should be balloted prior to embarking on a strike is a debate that has been ongoing for several years in South Africa. The argument for balloting members prior to participating in a strike is that it is important to establish whether the majority of members of the union that intends to call a strike support the proposed industrial action. The need for the balloting of members prior to a strike is informed by the fact that strikes in South Africa are often characterised by violence. It is also a common feature of strikes in South Africa that they tend to go on for an unreasonably long time. Violent strikes can cause massive damage to property and injury to people while prolonged strikes result in the retrenchment of workers on the basis of operational requirements because the business is not making a profit. 
Dismissal of employees is always a blow in South Africa where unemployment levels are extremely high. It is well known that high levels of unemployment lead to poverty. With a view to averting the effects of long and violent strikes, this article supports the balloting of members of a union prior to and during the course of a strike. The purpose of a pre-strike ballot is to test whether the strike has the support of the majority of the members of the convening union. Balloting members during the course of a strike also helps establish whether workers still have the appetite to continue with the strike. The ballot requirement is, however, not favoured by unions as they believe it takes away the right of workers to participate in a strike. In fact, the right to strike is entrenched in the Constitution and can only be removed if Parliament follows a specific procedure. The return of the ballot requirement into our labour law could help prevent job losses that result from dismissal on the basis of operational requirements due to protracted strikes.

\section{STRIKES AND BALLOT REQUIREMENT}

The right of workers to participate in a strike is derived from the Constitution. ${ }^{1}$ The Constitution provides that "every worker has the right to form and join a trade union; to participate in the activities and programmes of a trade union; and to strike". ${ }^{2}$ The Constitution further provides that national legislation may be enacted to regulate collective bargaining. ${ }^{3}$ As a result, the Labour Relations Act ${ }^{4}$ (LRA) was enacted in 1995. It defines a strike as:

"the partial or complete concerted refusal to work, or the retardation of work, by persons who are or have been employed by the same employer or by different employers, for the purpose of remedying a grievance or resolving a dispute in respect of any matter of mutual interest between employer and employee, and every reference to 'work' in this definition includes overtime work, whether it is voluntary or compulsory."

In giving effect to the provisions of the Constitution relating to strikes, the LRA draws a distinction between protected and unprotected strikes. In terms of the LRA, a strike is protected if there is compliance with sections 64(1) and 65(1) of the Act. Section 64(1) contains the procedure to be followed by a union or anyone intending to call a strike. Section 65(1) sets out the circumstances in which a strike is prohibited. In return for compliance with the provisions of the LRA, the legislature offers employees who organise, encourage or participate in protected strikes immunity from civil action except if they commit misconduct. ${ }^{6}$ Participants in a protected strike may also be dismissed on the basis of the operational requirements of the business, whether or not these arise as a direct result of the strike. ${ }^{7}$ In addition, participation in a protected strike does not constitute breach of

The Constitution of the Republic of South Africa, 1996.

S 23(2) (a) $-(c)$ of the Constitution.

$\mathrm{S} 23(5)$ of the Constitution.

66 of 1995.

$S 213$ of the LRA.

$S 67(6)$ of the LRA.

Whitear-Nel "Can Unidentified Protected Strikers Engaging in Misconduct be Retrenched? FAWU on behalf of Kapesi \& Others v Premier Foods Ltd t/a Blue River Salt River" 201123 SA Merc LJ 269276. 
contract, but is rather a suspension of the operation of the contract of employment. ${ }^{8}$ A protected strike results in a situation where employees are temporarily relieved of their obligation to render service in terms of their contracts of employment, and the employer is temporarily relieved of its obligation to remunerate the employees.

On the other hand, if there is non-compliance with the requirements laid down in section 64(1) or the facts fall foul of section 65(1) of the LRA, the strike is unprotected. Unprotected strikes are treated in the same way that strikes were treated in terms of the common law - that is, as a breach of contract for which the participants may be interdicted, sued for damages, or dismissed for failing to follow the applicable and relevant laws that regulate the contract of employment. ${ }^{10}$ If a strike is unprotected, the employer is at liberty to take action against the striking employees. The employer may claim compensation or damages from the employees if loss or damage is proved to be as a result of the strike. ${ }^{11}$ The Labour Court has powers to restrain such workers from continuing with their unprotected action.

A noticeable feature of section 64(1) of the LRA is the absence of a ballot requirement as a precondition for a protected strike. This means there is no obligation on unions to ballot members prior to embarking on a strike in terms of the LRA. However, the LRA does not prohibit unions from balloting their members if they do so in terms of their constitutions. ${ }^{13}$ In terms of sections 64(1) and 65(1) non-compliance with a union's constitution, however, does not render a strike unprotected. It is submitted that this is inadequate in terms of preventing violent and long strikes in South Africa. Things have changed, and the methods workers use to convey their demands have also changed, all of which point to the need for speedier resolution of disputes. It seems that available avenues are failing to deal with violent and protracted strikes in South Africa. As a result, the paper proposes the reintroduction of a strike ballot as a precondition for a strike to attain protected status.

\section{Can the right of workers to participate in a strike be taken away?}

Unions have complained that the reintroduction of a pre-strike ballot will take away their right to strike. This may not be true because the right to strike is entrenched in the Constitution. ${ }^{14}$ The interim Constitution, ${ }^{15}$ and later the final Constitution, ${ }^{16}$ ushered in an innovative phase in the evolution of South

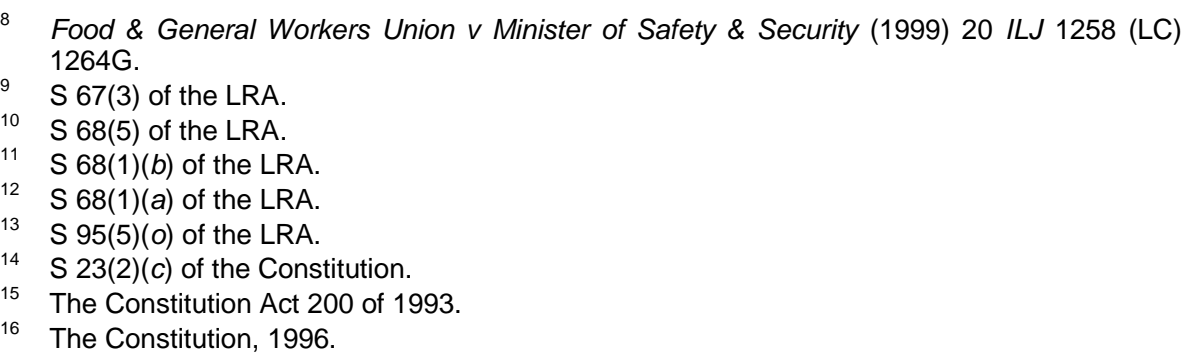


African labour law. ${ }^{17}$ The Constitution is the supreme law of South Africa. ${ }^{18}$ It provides "the people of South Africa" with the means to "heal the divisions of the past and establish a society based on democratic values, social justice and fundamental human rights". ${ }^{19}$ One of its express goals is to improve the quality of life of all citizens and to free the potential of each person. ${ }^{20}$ Most importantly, the Constitution contains the Bill of Rights. ${ }^{21}$

The rights guaranteed in the Bill of Rights must be properly understood as being part of the Constitution as a whole, and as a significant element of the Constitution's aim in the project of transforming South African society and the country's political and legal systems. ${ }^{22}$ None of the rights in the Bill of Rights, including those conferred on employees (such as the right to strike, picket, and protest) are absolute, as they must be exercised within the limits of the law and the LRA, in particular. The constitutional rights of employees may also be limited by the rights of others and also in terms of the limitation clause in the Constitution. The limitation clause provides that any limitation of a right in the Bill of Rights may only occur in terms of "law of general application", and after taking into account certain listed factors. ${ }^{23}$

If the right to strike is entrenched in the Constitution, workers cannot be stopped from exercising it and from participating in the activities of their trade union unless attempts to stop them are made in terms of the limitation clause of the Constitution. If the limitation is justified, however, it would not mean there would be no strikes in the future. The right to strike will remain available to workers unless the Constitution is amended. Amending a right guaranteed in the Bill of Rights of the Constitution requires that a two-thirds majority in the National Assembly and six out of the nine provinces represented in the National Council of Provinces vote in favour of the amendment. ${ }^{24}$

7 See Du Toit "Labour and the Bill of Rights" in Bill of Rights Compendium (1997) 4B-3.

18 S 2 of the Constitution provides that "the constitution is the supreme law of the Republic; law or conduct inconsistent with it is invalid, and the obligations imposed by it must be fulfilled".

19 The Preamble to the Constitution.

20 The transformative character of the Constitution is further evidenced in its first section, which describes the State as being founded on the "achievement of equality" (s 1), and in s 7(2), which requires the State to "respect and protect" as well as to "promote and fulfil the rights in the Bill of Rights".

21 Chapter 2.

22 Currie and De Waal The Bill of Rights Handbook 6ed (2013) 1.

$23 \mathrm{~S} 36$ of the Constitution provides:

(1) The rights in the Bill of Rights may be limited in terms of law of general application to the extent that the limitation is reasonable and justifiable in an open and democratic society based on human dignity, equality and freedom, taking into account all relevant factors, including -
(a) the nature of the right;
(b) the importance of the purpose of the limitation;
(c) the nature and extent of the limitation;
(d) the relation between the limitation and its purpose; and
(e) less restrictive means to achieve the purpose.

24 S 74(3) of the Constitution. 


\section{RATIONALE BEHIND THE NEED TO REINTRODUCE A BALLOT REQUIREMENT INTO SOUTH AFRICA'S INDUSTRIAL RELATIONS}

It has been stated above that the right to strike is one of the rights available to workers in terms of the Constitution. However, the length and violent nature of strikes over the past decade has led employers and sections of government to question the right to strike. On the one hand, some employers have suggested the need to curtail the right to strike, while on the other hand, sections of the labour movement have responded defensively, arguing that the right to strike is under threat. ${ }^{25}$ COSATU also added its voice to this issue, describing the proposal in the Labour Relations Bill of $2012^{26}$ as the "greatest threat to the right to strike since the fall of apartheid" ${ }^{27}$ The Bill had proposed that a strike would need to comply with following requirements to be protected:

“(iii) the trade union or the employers' organisation, as the case may be, has to conduct a ballot of its members in good standing who are entitled to strike or lock-out in terms of this section in respect of the issue in dispute; and

(iv) a majority of the members of the trade union or employers' organisation who voted in that election have voted in favour of the strike or lock-out."

In a democratic country like South Africa, strikes are normal and it is not surprising to see numerous strikes taking place each year. However, when strikes are violent and take a long time to be resolved, with negative effects on the economy, they are a problem.

There is, however, a perception among unions and employees that the withdrawal of labour on its own is not enough to convince the employer about the seriousness of their demands. The perception concludes that the effectiveness of industrial action depends on the degree of violence inflicted on the employer, non-striking employees, and members of the public. In 2006, a strike in the private security industry was violent. It lasted for three months and led to 57 deaths. On the issue of violent strikes, one worker remarked:

"There is no sweet strike, there is no Christian strike ... A strike is a strike.

You want to get back what belongs to you. You won't win a strike with a Bible.

25 The research arm of the Congress of South African Trade Unions (COSATU), the National Labour and Economic Development Institute (NALEDI), held a workshop on 10 September 2014 on the right to strike. One of the presenters argued that the right to strike was under threat because of the demands by some employers for the reintroduction of a ballo requirement in the LRA. The current position is that unions with protected strikes are required to include balloting in their constitutions, and the Department of Labour recently sent letters to unions asking how they were dealing with this requirement. Irvin Jim of the National Union of Metal Workers of South Africa (NUMSA), saw this as an "attack on workers' right to strike" Marrian "Set on Expansion of Scope Despite Cosatu Objection" (2014-12-19) Business Day 3.

26 Labour Relations Amendment Bill of 2012.

27 http://www.bdlive.co.za/articles/2012/05/03cosau-gets-planned-limit-on-right-to-strikescrapped;jsessionid=3BF6DA8A59CF6F10C05D8B2AE3E21B71.present1.bdfm .

28 Clause 6(a) of the Labour Relations Amendment Bill of 2012. 
You do not wear high heels and carry an umbrella and say '1992 was under apartheid, 2007 is under ANC'. You won't win a strike like that."

Von Holdt argues that workers use violence during strikes because it is inherent in the meaning of a strike, and it has proven to be effective throughout the years. He explains this as follows:

"Violence is a necessary element in maintaining the solidarity of the union and strengthening negotiations. A strike is a power struggle and has its own morality, which is not affected by the fact that South Africa is now a democracy with the former liberation movement in government."

The duration of strikes in South Africa has also been a concern to many people, including employers, employees, government, and other people who may be directly or indirectly affected by strikes. In 2014, then-Deputy President Cyril Ramaphosa acknowledged that the duration of strikes in the platinum and manufacturing industries was particularly worrying, and that their damaging effects gave rise to renewed calls for changes to labour legislation. ${ }^{31}$ There are several examples of strikes that took a long time to be resolved and had a damaging effect on the economy. In 2007, public servant employees went on a strike that lasted for 28 days, affecting schools and hospitals. In 2010, another strike by public servants lasted three weeks, costing the economy an estimated R1 billion a day. A significant number of the strikers were essential service workers, despite the LRA's prohibition of strikes and lock-outs in essential services. ${ }^{32}$ According to Thompson:

"[i]t was accompanied by a great deal of violence and intimidation, including the loss of life amongst hospital patients. Much of the action was unprocedural, offending against the requirements of governing legislation, including the prohibition against strike action in essential services."

In August 2012, a wildcat strike started in Marikana at the Lonmin Mine. The strike ended in September and resulted in the death of a total of 46 people. In 2014, almost 70000 employees in the platinum sector went on strike. It was the longest strike in the history of South Africa and lasted for four months. The platinum industry lost $\mathrm{R} 24$ billion in revenue. In March 2016, workers employed by waste removal company Pikitup downed tools leaving garbage largely uncollected, so causing health hazards for people. The strike lasted for 23 days.

The question that arises then is whether existing labour law can provide platforms for quick resolution of labour disputes to reduce the number of days that workers are not at work discharging duties in terms of their contract of employment. Persistent and prolonged strikes in South Africa signal a deficiency in the rules or principles regulating labour relations. But how should this problem be dealt with? Again, the article supports the

29 Von Holdt "Institutionalisation, Strike, Violence and Local Moral Orders" 2010 72/73 Transformation: Critical Perspectives on Southern Africa 127141.

30 Von Holdt 2010 Transformation: Critical Perspectives on Southern Africa 151.

31 "Nedlac Members Need to Address Trust Deficit" (2014-09-08) Business Day 4.

$32 \mathrm{~S} 65(1)(d)$ of the LRA.

33 Thompson Recipes for Public Service Success: Looking for Answers in South Africa \& Sri Lanka Paper presented at $17^{\text {th }}$ ILERA World Congress (7-11 September 2015) 10 , https://www.ilera2015.com/dynamic/full/il183.pdf. 
introduction of a ballot requirement as one of the procedural requirements for a protected strike. The purpose is to prevent industrial action from taking place in circumstances where it does not enjoy majority support and to quell violence against non-striking workers. At present, minority members of a union can stage industrial action, regardless of the will of the majority, by simply complying with sections 64(1) and 65(1) of the LRA.

\section{$4 \quad$ BALLOT}

In industrial relations, a ballot can be described as the means by which workers or union leadership determine the level of support for a proposed strike or industrial action. Usually, it takes place by means of a show of hands, and a simple majority is used to determine how many workers are in support of a strike and how many are against the proposed strike action. If most members balloted vote in favour of the proposed strike, it will go ahead. If it is the other way round - that is, if the majority of workers balloted vote against the strike - it should not go ahead.

Voting can also take place through a secret ballot. ${ }^{34} \mathrm{~A}$ secret ballot by members means that all members of the union who are eligible to vote must vote either in favour of or against a proposed strike. Du Plessis argues that the Commission for Conciliation, Mediation and Arbitration (CCMA) should be invited to assist during the voting process. ${ }^{35}$ After the voting process, the CCMA should issue a certificate to the effect that a ballot has been properly conducted and such a certificate will serve as proof that the union has complied with the provisions relating to ballots.

\section{Ballot requirement prior to the LRA}

The issue of balloting union members prior to embarking on a strike is not new in South Africa. It was a requirement in terms of the previous Labour Relations $\mathrm{Act}^{36}$ that unions must ballot members before embarking on a strike. Section $65(2)(b)$ of that Act provided:

"no trade union and no office bearer, official or member of such union shall call or take part in any strike or lock-out by members of the union unless the majority of the union or organisation in good standing in the area and in the particular undertaking, industry trade or occupation in which the strike or lockout is called have voted in favour of such action."

Section $8(6)(b)$ of the 1956 legislation further provided that all voting by ballot must be held in secret and that ballot papers must be retained for three years. However, the ballot requirement under this legislation did not succeed in curbing violence during that period. In the 1980s, community organisations formed alliances with the trade union movement to fight against the political system that was hostile to workers and society. ${ }^{37}$ As a

\footnotetext{
See s 95(9) of the LRA as amended by the LRAA of 2018.

Du Plessis and Fouché A Practical Guide to Labour Law 7ed (2012) 387.

28 of 1956.

37 Webster "Marikana and Beyond: New Dynamics in Strikes in South Africa" 2017 8(2) Global Labour Journal 148.
} 
result, it was difficult to separate industrial action from political violence. ${ }^{38}$ Consequently, the ballot requirement was considered to be ineffective for establishing the real number of employees who wanted to go on strike.

In addition, employers could interdict employees on the grounds that there were irregularities in the way a ballot had been conducted. ${ }^{39}$ If employees participated in a strike where there were irregularities (in the employer's view), the latter was quick to dismiss employees on the grounds that they had participated in an illegal strike. In short, complaints of non-compliance with the ballot requirement became a source of tension between unions and employers. ${ }^{40}$

Decisions on the ballot requirement also showed that the system under the 1956 labour legislation was abused by employers. In KwaZulu-Natal Furniture Manufacturers' Association v National Union of Furniture \& Allied Workers of South Africa, ${ }^{41}$ the employer sought to interdict the union and its members from participating in a strike that, according to the employer, was unlawful because the ballot was defective. The grounds for such an interdict were:

(a) the ballot was not conducted in secret;

(b) the union failed to give each member notice of three days to conduct the ballot;

(c) no scrutineers were appointed;

(d) the ballot was not conducted in terms of the union's constitution, which required it to be conducted at the union's branch offices;

(e) there was no inspection of ballot boxes by scrutineers; and

(f) the union failed to establish that the majority of its members voted in favour of a strike.

The court found that the strike ballot was irregular, invalid and unlawful, and not a proper ballot in terms of section $65(2)(b)$ of the LRA of $1956 .{ }^{42}$

In National Union of Metalworkers of $S A v$ Jumbo Products $C C{ }^{43}$ the court laid down a set of onerous guidelines to be observed by unions when conducting a ballot prior to a strike. These were described as harsh and aimed at frustrating the process of balloting members and gave the employer another opportunity to challenge the legality of a strike. ${ }^{44}$ In this context, participation in a lawful (now protected) strike was difficult. It seems

38 During the 1980s, community organisations formed alliances with the trade union movement. However, the widespread and intense protests since 2005 have not yet led to joint union-community action.

39 See Sasol v SACWU (1990) 11 ILJ 1010 (LAC).

40 See NUMSA $v$ Jumbo Products CC (1991) 12 ILJ 1048 (IC).

41 [1996] 8 BLLR 964 (N).

42 KwaZulu-Natal Furniture Manufacturers' Association v National Union of Furniture \& Allied Workers of South Africa supra 968.

43 (1991) 12 ILJ 1048 (IC).

44 Parfitt "Work-Place Ballots: Rules and Procedures" (1992) 13 ILJ 294. See also Media Workers Association v Perskor (1989) 10 ILJ 441 (LAC) 453H; Sasol Industries (Pty) Ltd v SA Chemical Workers Union (1990) 11 ILJ 1011 (LAC) 1030E-G; Chemical Workers Industrial Union v Bevaloid (Pty) Ltd (1988) 9 ILJ 447 (IC) 450E; White v Neil Tools (Pty) Ltd (1991) 12 ILJ 368 (IC) 372A-C. 
that because of these obstacles in the process of balloting union members, this requirement was not included in the LRA of 1995.

\section{Ballot requirement under the LRA and possible amendments}

Prior to the implementation of the Labour Relations Amendment $\mathrm{Act}^{45}$ (LRAA) the LRA did not require unions to ballot members prior to participation in a strike. This was voluntary depending on whether the constitution of the union requires members to be balloted. ${ }^{46}$ However, in terms of section 19 of the LRAA, unions are now obliged to have a provision in their constitutions that require members to be balloted before they participate in a strike. This is however, not a requirement for a protected strike since the failure to comply with this provision will not affect the status of a strike but it will be an internal issue within the union. ${ }^{47}$ Even if prescribed by the union's constitution, a pre-strike ballot is not a requirement for protection. ${ }^{48}$ In terms of the LRA, it is sufficient for the union to stage a protected strike if it has complied with sections 64(1) and 65(1) of the same Act. The Labour Relations Amendment Bill of 2012 had proposed a provision that would have required unions to hold a ballot prior to participating in a strike. ${ }^{49}$ This provision was, however, withdrawn from the Bill. The reasons for this withdrawal was strong criticism from trade unions, particularly from COSATU. ${ }^{50}$

\section{Ballot requirement and the constitution of a union}

Although the LRA does not require a ballot to be held before a strike can be called legally, a union may be obliged to call one in terms of its own constitution. ${ }^{51}$ In terms of section $67(7)$ of the LRA, failure to comply with a union's own constitution will not render the strike unprotected. ${ }^{52}$ However, the LRAA has reintroduced secret balloting of members in section 95(8) and (9) of the LRA, which now provides:

“(8) The Minister, after consultation with NEDLAC, may by notice in the Government Gazette publish ... guidelines for the system of voting as contemplated in subsection (9);

(9) for purpose of subsection (5), 'ballot' includes any system of voting by members that is recorded and in secret."

The amendments to section 95 of the LRA do not change the position of balloting prior to embarking on a strike. In terms of the provisions of the LRAA, where a union's constitution makes provision for a ballot to be

8 of 2018.

$S 95(5)$ of the LRA.

S $67(7)$ of the LRA.

48 Grogan Workplace Law 12ed (2017) 415

49 See clause 9(a) of the Labour Relations Bill of 2012.

50 Rycroft "Strikes and Amendments to the LRA" 201536 ILJ 7.

51 S 95(5)(o).

52 In terms of $s 67(7)$, non-compliance with such constitutional requirements will not render a strike unprotected. 
conducted prior to a strike, such ballot must be conducted. In Mahle Behr SA (Pty) Ltd v NUMSA; Foskor (Pty) Ltd v NUMSA ${ }^{53}$ the applicants applied to the Labour Court to interdict the respondents from engaging in a strike until a secret ballot was conduct by NUMSA. The Labour Court considered whether the transitional provisions in the Amendment Act applied to the respondents. NUMSA argued that the transitional provisions infringed the constitutional right of the union and its members to strike. The court held that the requirement to conduct a secret ballot did not constitute an infringement on the right to strike. In terms of the new transitional arrangements in the LRAA all unions and employer's organisations are required to have a provision in their constitutions that require the union or the organisation to conduct a secret ballot of members before engaging in a strike or lock-out. ${ }^{54}$ On the other hand section 67(7) of the LRA provides that the failure of a trade union to comply with a provision in its constitution regarding a ballot may not give rise to or constitute a ground for any litigation affecting the legality of section conferred on the strikers. Therefore, despite these amendments, the article argues that there is still a need to amend the LRA to make the balloting of members a requirement for a protected strike in South Africa. In this regard, section 64(1) would need to be amended to require balloting before a strike will be protected. If section 64(1) were amended to require a compulsory ballot, a failure to comply would render a strike unprotected.

Although the current LRA does not make provision for a compulsory ballot prior to a strike, this does not mean that the Act does not anticipate that a union constitution may require a ballot to take place before union members may participate in a strike. In this regard, the LRA provides in section 95(5) that the constitution of any registered trade union must:

"(o) establish the circumstances and manner in which a ballot must be conducted;

(p) provide that the trade union, before calling a strike, must conduct a ballot of those of its members in respect of whom it intends to call the strike;

(q) provide that members of the trade union may not be disciplined or have their membership terminated for failure or refusal to participate in a strike if-

(i) no ballot was held about the strike; or

(ii) a ballot was held but a majority of the members who voted did not vote in favour of the strike."

The LRAA provides that the voting must be "recorded and ... secret". Unions may want to be seen to be democratic and to be operating democratically. In this regard, some unions prefer to hold at least a meeting, and have a show of hands before calling a strike. This gives employees the freedom to vote against or in favour of the proposed strike. Only if the majority of members vote in favour of the strike, does the union have a mandate to go ahead with industrial action. ${ }^{55}$ However, if a union disregards the outcome of the internal ballot in terms of the union constitution and

\footnotetext{
Case No D448/19.

S 19 of the LRAA.

See the Memorandum of Objects of the Labour Relations Amendment Bill 2012.
} 
proceeds with the strike, such a strike will not be unprotected, provided the other requirements for a protected strike have been complied with. ${ }^{56}$

In addition, if a union calls a strike despite its constitution requiring a ballot to be held prior to a strike, the members of the union can approach the Labour Court to compel the union to respect the outcome of the ballot as provided for in its constitution. ${ }^{57}$. Trade union member(s) can also claim compensation from the union for wrong advice.

If a ballot is made a requirement for a protected strike, the process of casting votes will give the union leadership the opportunity to advise its members on how to conduct themselves during a strike (at the time of the ballot and afterwards) - an opportunity that the union must exercise faithfully, honestly and with care and diligence, considering that it could be held accountable for the actions of its members during the strike or picket. ${ }^{58}$ The possibility that violence could erupt under these circumstances is probably minimal, as employees will have reached consensus and will not act as fragmented factions. In the end, ballots can offer legitimacy, transparency and inclusivity to the process leading up to a strike.

The aim of balloting members before a strike is to prevent industrial action that has little or no support. There are several reasons for the eruption of violence during strike action. One is fear that the employer will continue with production and make profit as normal without feeling the economic harm that employees want to inflict. This may happen where industrial action enjoys little support since the question then arises whether the employer feels harm as a result of the withdrawal of labour if a reasonable number of employees are not on strike and continue with their normal duties. If the answer is in the negative, the danger of violence emerges. In Security Services Employers Organisation v SA Transport \& Allied Workers Union (SATAWU), ${ }^{59}$ the strike was convened by SATAWU. During the strike, it was reported that about 20 people were thrown out of moving trains in Gauteng Province; most of them were security guards who were not on strike and who were believed to be targeted by their striking colleagues. Two of them were killed, while others ended up in a serious condition in hospital.

In Food \& Allied Workers Union obo Kapesi v Premier Foods, ${ }^{60}$ certain of the workers at the Salt River plant chose not to participate in the strike. Several of these workers, as well as members of management, were thereafter subjected to violent acts of a severe criminal nature. The court heard that during the strike, several non-striking employees and members of the management were subjected to violent criminal acts: employees were threatened with physical harm and death and were assaulted; homes were fire-bombed; cars were set alight; one employee who identified his attackers was shot and killed; and a conspiracy to assassinate a director was uncovered. The court held that strikers should not be allowed to terrorise

56 See ss 64(1) and 65(1) on the requirements for a protected strike.

57 S 158(1)(e) of the LRA.

58 See Food \& Allied Workers Union v Ngcobo (2013) 34 ILJ 1383 (SCA) 1397; David Trust v Aegis Insurance Co Ltd 2000 (3) SA 289 (SCA) par 20; Bloom's Woollens (Pty) Ltd v Taylor 1962 (2) SA 532 (A) 539G-H.

59 (2006) 27 ILJ 1217 (LC).

60 (2010) 31 ILJ 1654 (LC). 
and harm non-striking workers with impunity. ${ }^{61}$ This means that it is crucial that a strike should go ahead only if the majority of employees supports the strike so that no or little production then takes place. If it is the other way round, those employees who participate in the strike might perceive that the employer does not feel the economic harm - since most of the workforce would be providing services and, for the employer, it would be business as usual. The possibility is that strikers will then start to victimise non-striking employees, ${ }^{62}$ using various means such as intimidation, assaults and killing of those who offer their services. ${ }^{63}$ It is not only non-striking employees who become victims; replacement labourers and members of the public also face the same treatment. ${ }^{64}$ It is suggested that all members of the union should be balloted prior to a strike, and they should have to be balloted again after two or three weeks until the strike has ended. Balloting members every two or three weeks after an original ballot would help to test the appetite of workers to continue with the strike.

\section{AMENDMENTS TO THE LRA}

Although in terms of the new amendments to the LRA unions are compelled to have a provision in their constitutions that will allow members to vote before going on strike, this is however, not equivalent to a requirement for a protected strike. A failure to comply with this will constitute an internal deficiency within the union. This article proposes amendments to section 64(1) of the LRA to accommodate the provision of a ballot. The process of reintroducing a ballot requirement into our labour law will not be easy, since it has to be deliberated and agreed by the parties involved at the National Economic Development and Labour Council (NEDLAC). The parties at NEDLAC have been at loggerheads on the issue of a ballot as a requirement for staging a protected strike. In 2012, a ballot requirement was proposed in an Amendment Bill but was shot down by labour. ${ }^{65}$ It is submitted that labour should be consulted widely and be convinced that the return of a pre-strike ballot will not take away their right to strike but instead would be a means to address long and violent strikes that are detrimental to both employees and employers.

A secret ballot is no longer a statutory requirement for a protected strike or lock-out, as it was in terms of the 1956 LRA. It could be argued that although the old Labour Relations $\mathrm{Act}^{66}$ contained a secret ballot requirement, that did not deter unions from engaging in violent behaviour, and may also not help prevent long strikes in the current industrial environment. In response, it is submitted that since political violence has

\footnotetext{
Food \& Allied Workers Union obo Kapesi v Premier Foods supra par 56. Ibid.

63 "Cape Town Striker Fighting for His Life" (2012-10-10) News24 reported that "a certain Mr Stewart who was traveling on a truck was next to the Cape Town International Airport when the vehicle was stoned by strikers and was hit on the head with a brick", https://www.news24.com/SouthAfrica/News/Cape-Town-trucker-fighting-for-his-life20121010.

64 See Mahlangu v SATAWU, Passenger Rail Agency of SA (2014) 35 ILJ 1193 (GSJ).

65 Labour Relations Amendment Bill of 2012.

$66 \mathrm{~S} 65(2)(b)$ of the Labour Relations Act 28 of 1956.
} 
diminished in South Africa, the existing labour law needs to be refashioned so that it can deal decisively with the harmful effects of violent and protracted strikes. In this regard, it is argued that if a ballot requirement could be added to our labour law, as one of the requirements for a protected strike, it could play a positive role in addressing strike-related violence. For example, if most employees who are members of the union voted in favour of a strike, the employer might see the seriousness of the employees' demands and reconsider its position at the negotiating table before the strike commences. Holding a ballot prior to a strike has certain advantages for the union, since it is a mandate-driven organisation. If a union does hold a ballot before calling a strike, and the ballot is in favour of the strike, the union will have a mandate and sufficient support from its members to go ahead with the proposed strike. The possibility that violence could erupt under these circumstances is then minimised since employees will have reached consensus and would not act as fragmented factions.

As stated above, if a strike enjoys majority support, violence is less likely to occur; if the strike has little support and the employees are divided, the possibility of harm to the employer and its property is higher. The striking employees usually turn against those employees who are not on strike. ${ }^{67}$ The reason for this is the fear that the employer might not feel the economic harm they want to inflict, since they can continue with production despite the strike action. The more economic pressure put on the employer, the bigger the likelihood that the employer will accede to the demands of employees as they will be left with little or no workforce to continue with production.

Having a ballot requirement as one of the requirements for a protected strike in South Africa will not only bring democracy to the workplace but, from the trade union perspective, it could prevent the disappointment that can result from a failed strike because of lack of support from other employees. ${ }^{68}$ The great advantage of having a ballot prior to a strike, for both employers and unions, is that it encourages employers to settle before employees resort to a strike. It also acts as an early-warning mechanism. For example, 50000 workers were balloted in SACWU in 2013, and 85 per cent supported a strike. A strike was then pre-empted when the employers settled. If balloting members prior to a strike were to be made a requirement for a protected strike, a failure to comply would render the strike unprotected, and the consequences of an unprotected strike would then follow. ${ }^{69}$

The reintroduction of a ballot requirement into the LRA is not new; prior to the coming into effect of the Labour Relations Amendment Act (LRAA) of 2014, the legislature had proposed its inclusion in the LRA. ${ }^{70}$ Unfortunately,

67 Security Services Employers' Organisation v SA Transport \& Allied Workers Union (2006) 27 ILJ 1217 (LAC).

68 Jacobs argues that in a 2011 wage strike by municipal workers, only 16166 out of 208359 municipal workers nationally supported the strike. The strike failed due to lack of support (Jacobs What Contributed to the Failure of 2011 Municipal Strike? (LLM dissertation, University of Cape Town) 2013.

69 S 68 of the LRA in this regard. See also Budeli The Impact of the Amendments on Unions and Collective Bargaining Paper presented at $27^{\text {th }}$ Annual Labour Law Conference, Sandton Convention Centre, Johannesburg (5-7 August 2014).

70 Labour Relations Bill of 2012. 
the proposed amendments were scrapped from the 2012 Labour Relations Bill that gave birth to the LRAA owing to strong criticism from labour. Rycroft argues that the removal of the ballot requirement from the 2012 Bill was not expected as is was not a threat to both unions and members. ${ }^{71}$ He further states that "all that was required by this proposed provision was a ballot of members in good standing; such members being eligible to vote with respect to the issue in dispute; and a majority of members who voted in that election had voted in favour of the strike". This means that what was required in terms of the now-defunct ballot provision was that the majority of those members who voted must have elected to go on strike. It did not mean that the majority of union members should have voted in favour of the strike.

Although the ballot requirement was scrapped from the Labour Relations Bill of 2012, it is believed that the intention behind its inclusion was to respond to the high levels of violent and protracted industrial action in South Africa. The removal of the ballot requirement was a disappointment for those who wanted to see strikes with less or no violence and of short duration. The author views this removal as a lost opportunity by the legislature to prevent unreasonably long strikes, which are often characterised by violence and cause job losses.

The inclusion of a ballot requirement in the LRA could also bring with it some disadvantages. For example, it could hamper the negotiating process, and draw out the process over a period of time. However, such a delay could deliver a good result because, in the process, strikers could change their minds about the proposal to go on strike or the employer could change its mind about the demands of the employees. So, this may be viewed as both an advantage and a disadvantage depending on who is considering the issue.

\section{Secret ballot}

If balloting members prior to a strike is made a requirement for a protected strike, the article argues that the ballot must be secret. The LRAA 2018 hints at a move in this direction. ${ }^{72}$ This would be in line with our voting traditions, as it would reinforce worker control of unions. Von Webster believes that workers must have the sense of having democratic control of the strike and this would be ensured by a confidential balloting of members before and during the strike. ${ }^{73}$ If workers exercise democratic control of the strike, the possibility of strike violence would be reduced, and the union would be more likely to take responsibility for the consequences of the strike. In this way, the strike could be used more strategically and employers could respond more constructively.

The voting process must be fair and secret and there must be no intimidation of those who cast their ballot, or of those who do not want to vote. Concerns may be raised about the secrecy of the voting process. In

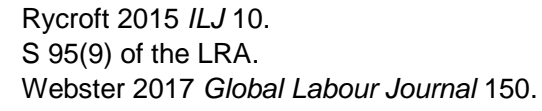


MAWU v Natal Die Casting, ${ }^{74}$ a ballot was conducted from the boot of a car near the company premises. The Industrial Court found that holding the ballot in the open, did not mean it was not secret. The court accepted that trade unions do not have the same facilities as employers. It said that what mattered was that the voter should not be put under constraint. In White $v$ Neill Tools, ${ }^{75}$ the court stated that the strike ballot provides the individual with an opportunity to cast his or her vote in secret and to consider the consequences of the contemplated action privately and without being unduly influenced, pressurised or intimidated by having to make choices in the open.

Voting secretly is important because, in a strike context, the employer is entitled to know that it is dealing with the majority of members in question, which is so demonstrated by a ballot properly conducted in terms of the law. ${ }^{76}$ A secret ballot, as opposed to a "hands-up" system, avoids the scenario of the union putting pressure on members to vote in favour of the strike. There is a strong belief that if voting takes place by a show of hands, intimidation may occur and some employees may be targeted by other employees. ${ }^{77}$ In addition, a secret ballot prior to a protected strike would ensure that strikes are taken seriously, and they are not viewed just as actions of "uncivilised hooligans" because of the current concomitant damage to property and the intimidation and killing of people.

Although the reintroduction of ballots was discussed before the introduction of the LRAA of 2018, the new amendments to the LRA on balloting members do not change the position and will not have any effect on violent and unprotected strikes. It can be argued that by removing the ballot requirement from the Amendment Bill of 2012, the legislature lost an opportunity to refashion and refresh strike law, taking into account contemporary social and economic realities. ${ }^{78}$ If a ballot requirement could be made law, strikes would only commence if the majority of the employees agreed, and that would lead to less intimidation of non-strikers and greater coherence among strikers. If the reintroduction of a secret ballot were given a chance, things might change for the better as a strike would go ahead if it was supported by a majority of the members. However, labour will have to be thoroughly consulted and convinced that the aim is not to disadvantage them, but rather to improve the economy and reduce the loss of jobs, which is the normal consequence of prolonged and violent strikes. A secret ballot ensures that the union has a democratic mandate for a strike, and, if necessary, further ballots can be held during negotiations, for example, when a provisional agreement is reached. In addition, if the ballot is secret, it prevents unions from putting pressure on employees to vote in favour of the strike. It would also ensure that the right to protected industrial action is not abused by union officials, who might want to push agendas unrelated to the interests of workers at the workplace concerned. Moreover, a secret ballot

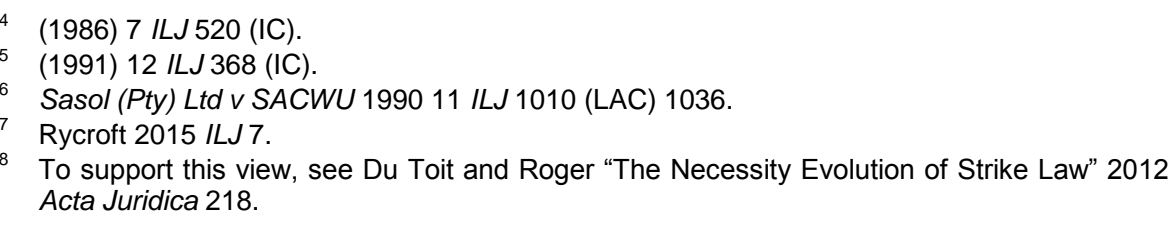


does not stand in the way of the protection of strike action, but provides a mechanism to ensure that a protected strike is the genuine choice of the majority of employees employed by the employer or in the workplace. If the vote is in favour of a strike, it means there is an appetite for it and perhaps the concerns or demands of employees are genuine. A secret ballot can also protect jobs by avoiding unnecessary strikes that may result in dismissal on the basis of operational requirements of the business. ${ }^{79}$ It is important to note that, in this context, employers can reduce the number of employees if the business is no longer making a profit; this might happen if no production takes place, which in turn results in a loss of customers. Importantly again, if a strike goes on for an unduly long period, customers or clients might shift loyalty to other businesses resulting in a loss of profit.

\section{BALLOT REQUIREMENT IN OTHER COUNTRIES AND LESSONS FOR SOUTH AFRICA}

In Australia, a ballot by members prior to industrial action is a statutory requirement. ${ }^{80}$ The purpose is to achieve a fair, simple and democratic process and to determine whether employees wish to engage in a particular protected action. ${ }^{81}$ It is important to note that before a ballot takes place, a union must apply to the Fair Work Commission (FWC) for permission to conduct a ballot. ${ }^{82}$ It is believed that the purpose of such an application is to notify or warn the Commission that a strike may take place so that it may prepare itself for the impending action by workers. The voting process is supervised by a third party - usually, the Australian Electoral Commission (AEC) or an authorised independent ballot agent. ${ }^{83}$ The process must be conducted by either of these to be valid. If it is not the AEC that will oversee the ballot, the union will make an application to the FWC to authorise the use of an independent ballot agent. The person proposed to act as ballot agent must be fit and proper. ${ }^{84}$ The strike will only go ahead if 50 -plus-1 per cent (of employees who voted) vote in favour of the proposed strike. If the majority of employees vote against the proposal to go on strike, it will not go ahead.

In Canada, the majority of Canadian jurisdictions require employees to cast their votes prior to a strike. ${ }^{85}$ Non-compliance with the requirement of a ballot prior to a strike renders such a strike unprotected and attracts legal remedies. $^{86}$ If the majority of the employees that were balloted vote in support of the strike, the strike may go ahead. However, if the majority of employees or members of the union vote against the proposed strike, the strike cannot proceed. The advantage of having a ballot prior to a strike is

\footnotetext{
S 189 of the LRA.

S 436 of the Fair Work Act of 2009.

S 436 of the Fair Work Regulations 2009.

Regulation 5(4) in terms of Industrial Relations (Pre-Strike Ballots) 1997.

83 Part 3-3, Division 8 of the Fair Work Regulations 2009 (Cth) sets out regulations for the conduct of secret ballots by the AEC.

84 Regulation 3.11 of the Fair Work Regulations 2009.

85 Alberta, British Columbia, Manitoba, New Brunswick, Nova Scotia, Ontario, Quebec, Carter and England Labour Law in Canada (2002) 293.

86 Carter, England, Etherington, Trudeau and Norwell Labour Law in Canada (2002) 293.
} 
that it may prevent an ambitious union leadership from taking a decision without consulting its members. ${ }^{87}$ It also helps to protect the interests of the employer against harmful strike action, and the interests of individual workers against strikes that are not democratically mandated. In the end, if workers vote against a proposed strike, the loss of wages arising from the "no work, no pay" rule will be prevented.

The Constitution of South Africa makes provision for reference to the law of other countries where necessary. ${ }^{88}$ In this regard, South Africa can learn from foreign law where its own law is not clear or not yet developed in a particular area of law. An example could be the issue of balloting members prior to a strike. Where a ballot is made a legal requirement for a protected strike, as is the case in Australia and in most Canadian jurisdictions, and if a majority of members vote against the strike, the strike cannot take place. If the union disregards the result of the ballot and proceeds with the strike, the strike is unprotected. The union and the members who participate in such a strike are then subject to the consequences of an unprotected strike. ${ }^{89}$ However, where a majority of employees vote in favour of a strike, it sends a strong signal to the employer that there is a collective determination to withhold labour, which can in turn change the employer's attitude towards bargaining on the issues in dispute. In this regard, a ballot would be more than a formality; it would be designed to ensure that the decision to strike reflects the will of the majority. ${ }^{90}$

In Australia and Canada, if a union fails to conduct a ballot, the employer may apply for an interdict to stop the union from calling a strike. The union then bears the consequences of its actions, and must take responsibility when claims of damage to property are lodged against it, although it has recourse against the members who actually committed the acts. The same should apply to South Africa if a union calls for a strike without having balloted members; and the remedies in terms of section 68(1) and (5) of the LRA should follow. These are interdict, compensation and dismissal.

On the question of who should conduct such a ballot, it is suggested that an independent body should oversee union ballots. The conduct of a ballot by an independent body would go a long way towards ensuring that industrial action is peaceful. The involvement of such a body or an alternative ballot agent would ensure that voting is fair, transparent and not biased toward or against rival factions. An independent electoral body such as the Independent Electoral Commission (IEC) or an authorised independent agent, could conduct such ballot. However, the volume of work in which the IEC is involved may make it impossible for the IEC to oversee trade union ballots. It is then proposed that an independent ballot agent (such as a representative from the CCMA) could be a suitable alternative.

The idea of a ballot has previously been discredited because employers used it during the apartheid years as a way to interdict strikes on the basis

\footnotetext{
Weiler Reconcilable Differences (1980) 70-74.

S 39(1) (c) of the Constitution.

$S 68$ of the LRA.

CWIU v Bevaloid (1988) 9 ILJ 447 (IC).
} 
that the ballot procedures were in some way defective. ${ }^{91}$ Webster argues that a ballot should not be reintroduced into the LRA as some employers argue; instead, it should be voluntary and should be an indication of the union's commitment to worker control by its members. ${ }^{92}$

\section{CONCLUSION}

Violent protracted strikes can have devastating effects on employers, employees and the economy at large. Despite the fact that workers have a constitutional right to strike, it is important that the exercising of such a right not be allowed to go beyond the necessary limits. Currently, strikes are often characterised by violent conduct. Resolution of strikes also takes a long time, leaving many people unemployed by the time a solution is found. This not only affects the employees concerned, but is a contributing factor to poverty. To prevent long and violent strikes from taking place, it is suggested that there should be changes to existing labour law so as to include a ballot requirement. The law should compel a convening union to ballot members before staging a strike. To be credible, the balloting process should be chaired by an independent body, such as the IEC or a representative from the CCMA. This is the position in Australia and Canada. In these countries, if a union calls a strike without having balloted its members, such a strike is unlawful and civil action can be taken against the union and its members. Balloting members prior to strike action would help to establish their willingness to embark on a strike. If the majority vote in favour of a strike, it would send a signal to the employer that workers are serious and that it must consider their concerns or demands in a serious light. The employer and employee representatives are expected to engage fruitfully during negotiations and to avoid impending industrial action.

\footnotetext{
91 Du Toit, Bosch, Woolfrey, Godfrey, Rossouw, Christie, Cooper and Bosch Labour Relations Law: A Comprehensive Guide (2003) 288.

92 Webster 2017 Global Labour Journal 152.
} 